\title{
CIVIL ASPECTS OF NATIONAL SECURITY Asen VODENITCHAROV
}

\author{
South-West University "Neofit Rilski”" Blagoevgrad, Bulgaria, \\ asenvodenicharov@mail.bg
}

\begin{abstract}
The article examines the national security as a state of society and state in which fundamental rights and freedoms of man and citizen shall be protected. It examines the interdependence between security in the civil society and the guarantees for full realization of the rights, freedoms and legal interests of citizens. It specifies the question for social security of citizens and legal entities in: signing and realization of civil transactions; the regime of entries; the exercise of ownership and development of the substantive law relations; the relocation of trade companies from Bulgaria in other EU Member State and from another EU Member State in Bulgaria. This scientific study underlines the need for improvement of the regulation of civil transactions, in order to ensure the maximum social security of citizens and legal entities and forming of a favorable environment for their dynamic development.
\end{abstract}

\section{Keywords: national security, legal security, civil aspects, registration, harmonization National Security and Civil Rights}

National security is a complex political, economic and legal category which is an exceptionally complicated social phenomenon. This phenomenon contains a number of elements that define it as a specific manifestation of social practice, which affects different spheres of public life not only in a certain geographical or administrative-territorial district or country, but also refers to an individual, professional group or category of population. Therefore, the national security can be defined as a status of the society and the state wherein the fundamental civil rights and freedom of man and citizen are protected, as well as the territorial integrity, independence and sovereignty of the country. It also guarantees the democratic functioning of the state and civil institutions. As a result, the nation retains and increases its wealth-being and development.

In this sense, the subjects of the national security of any country are the personality with its rights, freedoms and responsibilities; population as a whole with its traditions, material and spiritual values; the country with its established forms of polity and governance, law, national sovereignty, independence and territorial integrity, and its social system [1].

The Constitution of the Republic of Bulgaria raises in its Preamble as supreme principle the civil rights, dignity and security. Therefore, the safety of the individual is a substantial component of the national security, its essential feature and is a prerequisite for its continuous development.

The safety of the individual, as inseparable component of national security, has its civil, administrative and criminal law dimensions. Together they form the legal certainty, which above all puts into effect the rights, freedoms and legitimate interests of the individual citizen or groups of citizens. 
The methods of administrative law and other ranges of public law are important legal instruments for the establishment of rights or obligations. They are reliable means of protection against acts and actions of state authorities, which directly affect the rights, freedoms or legitimate interests of individuals or legal entities. Safety of the individual and society as a whole is carried out with the means of the specific criminal law.

\section{Security and Civil law}

The conditionality and the relationship between the security, the rights and the freedoms of the citizens in the civil law relations are particularly important. It is through these legal relations that a large number of the fundamental rights of the citizens laid down in the Constitution are carried out; they provide security in their occurrence, development and termination.

For these reasons, the problems of the civil law matters of the individual are subject to a number of regulations and directives of the institutions of the European Union [2].

A very large number of the cases of the Court of Justice of the European Union are related to securing and guaranteeing the rights and freedoms, as well as attaining the legitimate interests of the citizens and legal persons of civil nature [3]. The Court has established a practice of resolving the submitted disputes while respecting the rights and freedoms of the citizens of the Member States.

The legal certainty of the civil relations facilitates the development of the internal market. In accordance with art. 26 para. 2 of the Treaty on the Functioning of the European Union, it shall comprise an area without internal borders in which the free movement of goods and services and the freedom of establishment are guaranteed.

Means of implementation of the legal certainty, as an element of the national security

The legal transactions are the material means for accomplishing the abovementioned and for establishing legal certainty. There is no definition of legal transactions in the existing legislation. The analysis of individual legal norms reveals several important characteristics of the legal transactions. There are one or more statements of will of parties. When there is more than one statement, the wills are interrelated. The transaction is considered fulfilled when the wills overlap completely. The transactions always aim at achieving certain legal consequences in the area of private law. The intentions of the persons participating in the transaction determine the content of the desired legal consequences. Thus, the need for their legal certainty.

Legal certainty is particularly necessary in the exercise of rights in rem [4]. A number of them are related to the public state or public municipal property, which are used in the public interest.

The necessity for legal certainty, as a specific form of national security, can also be felt during the relocation of a trading company's headquarters from one Member State to another within the borders of the European Union [5].

An important factor for the legal certainty is the recording in the relevant registers of the newly established corporate entities, the changes in their legal status and the termination of their activities. This is particularly important for supranational companies. They are recorded in the Member State, where their headquarters are located, with respect to the legislation of that Member State and in accordance with the law applicable to joint-stock companies. In view of the legal status, the entry into the relevant register has legal effect in three directions:

a) Constitutive statement

The registration as a legal action has a particularly significant legal effect. Under the existing legislation, the Company shall acquire legal personality on the day of the entry in the register.

If acts are performed in the Company's name before its registration and the Company does not assume the obligations arising out of such acts after its 
registration, the natural persons, companies, companies or other legal entities which performed those acts shall be jointly and severally liable therefor, without limit in the absence of agreement to the contrary.

The abovementioned provision indicates that the entry has constitutive nature. It results in the emergence of a new legal entity.

b) Substantiated statement

The recorded data will be considered as valid and into effect until proven otherwise. Bona fide third parties can rely on the entry as well as the notification, even if the recorded circumstance, respectively the disclosed act, does not exist.

c) Declaratory statement with special importance for the legal certainty

The entries into the relevant register are considered known to the bona fide third parties from the date of recording of the entry. No legal entity can rely on ignorance with regard to the existing data in the register and therefore to damages suffered from it. Thus, the entry may be defined as an irrefutable presumption of knowledge of the recorded entries [6]. The act of entry under review has been explicitly regulated in the Commercial Register Act of the Republic of Bulgaria

[7], the Commercial Registration Act of Estonia [8], the Commercial Register Act of Spain [9] and others.

In contrast to the legal effects of the entry, its publication does not represent condition iuris for the emergence of the company.
The data recorded in the SCE has public status unless there is contrary legal provision. Art. L. 123-1 - II of the Commercial Code of France specifically stipulates that the entries of commercial and association registers shall be public [10]. Similar rules exist in the Commercial Register Act of the Republic of Bulgaria [11], the Business Register Act of Latvia, the Court Register Act of Slovenia and others.

The obligation to initiate legal proceedings falls on the management or administrative body of SCE. In general, the founders do not have capacity to bring proceedings in order to submit the statutory set of documents to the authorities laid down by the national law. The SCC of the Republic of Bulgaria has concluded that the decision for entry, claimed by unauthorized by the law person is legally null and subject to cancellation. Other judicial panels have concluded that the imposed judicial acts are null and void.

\section{Conclusion}

This scientific study underlines the need for improvement of the regulation of civil transactions, in order to ensure the maximum social and legal security of citizens and legal entities and forming of a favorable environment for their dynamic development.

It should be emphasized the necessity of a complex harmonization of the national legislation in the field of civil relations with the social regulation in the European Union as a part of the national security.

\section{References}

[1] Ivanov T. Management of Security and Defense, Sofia, Publishing House "Economy", 2008, with 348 с, Иванов Т. Мениджмънт на сигурността и отбраната, София, издателство „Стопанство”, 2008, 348 с.; Ionchev, D., Security Levels, Sofia, Publishing House "Prof. Marin Drinov ", 2009, 324 с, Йончев, Д.,Равнища на сигурност, София, издателство „проф. Марин Дринов”, 2009, 324 с.; Bakalov J., Knowledge as an Instrument of the Reforms in the Security System, Report presented to the International conference "Reforms in the national security system of the Republic of Bulgaria", pp. 105-112. Sofia, Bulgaria, September, 2014, Бакалов Й., Знанието като инструмент на реформите в системата на сигурност, Доклади на научна конференция „Реформите в системата за национална 
сигурност на Република България", с. 105-112. София, България, September, 2014; Mesjasz,Cz., Security as an Analytical Concept. Cracow University of Economics, Report presented at the $5^{\text {th }}$ Pan-European conference on International Relations, The Hague, Netherlands, 9-11 September 2004. p. 6.; Romm J. J., Defining National Security, The Nonmilitary Aspects, Council on Foreign Relation Press, New York, 1993, p. 408

[2] Council Regulation /EC/ № 44/2001 of 22 December 2000 on jurisdiction and the recognition and enforcement of judgments in civil and commercial matters, Official Journal L 012, 16/01/2001 P. 1; Regulation /EU/ № 1215/2012 of the European Parliament and of the Council of 12 December 2012 on jurisdiction and the recognition and enforcement of judgments in civil and commercial matters, Official Journal L 351/21, p.26 Regulation /EC/ № 805/2004 of the European Parliament and of the Council of 21 April 2004 creating a European Enforcement Order for uncontested claims; Official Journal L Regulation /EC/ № 1896/2006 of the European Parliament and of the Council of 12 December 2006 creating a European Order for payment procedure; Official Journal L Council Regulation /EC/ № 1346/2000 of 29 May 2000 on insolvency proceedings, Official Journal L

[3] Marin.N., Jurisdiction of the Court of Justice in the Area of Freedom, Security and Justice, Blagoevgrad, Bulgaria, University Publishing "Neophyte Rilski”, 2011, 384 c., Марин Н, Юрисдикция на Съда на Европейската общност в пространството на свобода, сигурност и правосъдие, Благоевград, България, Университетско издателство „Неофит Рилски”, 2011, 384 с

[4] Boiyanov G. Property Law, Sofia, Bulgaria, Avalon Publication, 2004, 462 c., Боянов Г., Вещно право, София, България, издателство Авалон, 2004, 462 с

[5] Vodenicharova,K., Influence of Systems of Connecting Factors on Company's Mobility in the European Union, annual science conference 2014, The issues of the legislation and the law appliance, concerning development of the business in the Republic of Bulgaria and Europe, Sofia, Bulgaria, the University of national and world economy, p. 194-204; Воденичарова К., Системи за привръзка на дружествата и влиянието им върху тяхната мобилност в Европейския съюз, Годишна научна конференция 2014 „Проблеми на законодателството и правоприлагането, свързани с развитието на бизнеса в Република България и Европа", София, България, Издателски комплекс на Университета за национално и световно стопанство, 2015, с. 194-204

[6] Stalev Zh., Bulgarian Civil Procedure Law, Sofia, Bulgaria, Publishing house "Ciela", 2010 с. 759; Сталев, Ж., Българско гражданско процесуално право, София, България, издателство „Сиела”, 2010, с. 759

[7] Art. 9, para. 2 of the Commercial Register Act states that submitted acts for entry are believed to have become known to third parties from the moment of delivery. Чл. 9, ал. 2 на Закона за тьрговския регистьр посочва, че представените актове за вписване се смята, че са станали известни на третите лица от момента на обявяването

[8] Чл. 47 от Част II от Äriseadustik, Vastu võetud 15.02.1995, RT I 1995, 26, 355, joustumine 01.09.1995, last amendment - 01.01.2011

[9] Ley de Sociedades Anónimas (Real Decreto Legislativo 1564/1989, de 22 de diciembre 1989

[10] Code de commerce, chapitre III. Des obligations générales des commerçants, Section première. Du registre du commerce et des sociétés, Sous-section 1. Des personnes tenues a l'immatriculation, art. L.123-1 II

[11] Commercial Register Act - art. 11. The commercial register is public. Everyone is 
entitled to free access to the database constituting the commercial register, State Gazette, issue 34 from 25.04.2006. Закон за търговския регистьр - чл. 11. Търговският регистьр е публичен. Всеки има право на свободен и безплатен достьп до базата данни, съставляваща тьрговския регистьр, ДВ, бр. 34 от 25.04.2006 